\title{
OPEM
}

www.opem.org

Oriental Pharmacy and Experimental Medicine 2008 8(4), 323-328

DOI 10.3742/OPEM.2008.8.4.323

\section{Antibacterial, cytotoxic and neuropharmacological activities of Cerbera odollam seeds}

\author{
F Ahmed $^{1, *}$, R Amin $^{2}$, IZ Shahid ${ }^{1}$ and MME Sobhani ${ }^{2}$ \\ ${ }^{1}$ Pharmacy Discipline, Khulna University, Khulna-9208, Bangladesh; ${ }^{2}$ Biotechnology and Genetic Engineering \\ Discipline, Khulna University, Khulna-9208, Bangladesh
}

Received for publication June 19, 2007; accepted January 07, 2008

\begin{abstract}
SUMMARY
The MeOH extract of seeds of Cerbera odollam Gaertn. (Apocynaceae) was screened for its antibacterial, cytotoxic and neuropharmacological activities. The extract showed moderate anti-bacterial activity against Salmonella typhi, Streptococcus saprophyticus, and Streptococcus pyogenes. It exhibited high level cytotoxicity against brine shrimp $\left(\mathrm{LC}_{50}: 3 \mu \mathrm{g} / \mathrm{ml}\right)$. The extract potentiated pentobarbital induced sleeping time in mice which was further supported by the exploratory behavior test at dose of $25 \mathrm{mg} / \mathrm{kg}$. The overall results tend to suggest the antibacterial, cytotoxic and CNS depressant activities of the extract.
\end{abstract}

Key words: Cerbera odollam; Antibacterial activity; Cytotoxic activity; CNS depressant activity

\section{INTRODUCTION}

Cerbera odollam Gaertner (pink-eyed cerbera, yelloweyed cerbera, odollam tree), also sometimes called Cerbera manghas $\mathrm{L}$, belongs to the notoriously poisonous Apocynaceae family, which also includes the yellow oleanders (Thevetia peruviana and Thevetia nerifolia) and common oleanders (Nerium oleander and Nerium indicum). The C. odollam tree grows to a height of $6-15 \mathrm{~m}$ and has dark green fleshy lanceolate leaves. The large white flowers have a delicate perfume, reminiscent of jasmine. The fruit, when still green, looks like a small mango, with a green fibrous shell enclosing an ovoid kernel measuring approximately $2 \mathrm{~cm} \times 1.5 \mathrm{~cm}$ and consisting of two cross-matching white fleshy halves. On exposure to air, the white kernel turns

\footnotetext{
*Correspondence: F Ahmed, Pharmacy Discipline, Khulna University, Khulna-9208, Bangladesh. Fax: 880-41-731244; E-mail: firoj72@yahoo.com
}

violet, then dark grey, and ultimately brown or black. The plant as a whole yields a milky white latex. The tree grows in coastal salt swamps and creeks in south India (particularly abundantly near the canals and backwaters of Kerala) and along riverbanks in southern and central Vietnam, Cambodia, Sri Lanka, Bangladesh and Myanmar. In Bangladesh the plant is known as Dabur, Dhakur or Um-dabur. The seeds have a long history as an ordeal poison in Madagascar, due to the highly toxic cardiac glycosides they contain. The seeds contain non-siccative oil, producing a shining flame with a pleasant nut-like odour. The Burmese use it for lighting, as a cosmetic, or mixed with other oils as an insecticide or insectrepellent (Chopra et al., 1956). The bark and leaves of the plant are traditionally used as emetic and cathartic; kernels are used as emetic; fruit is used as a cure for hydrophobia (Kirtikar and Basu, 1987). Its bark and fruits are purgative and used 
for the treatment of rheumatism (Rollet, 1981). Previously, we studied and reported the antinociceptive and sedative effects of its barks (Ahmed et al., 2006). Also some other research works have been performed to evaluate its biological activities as cytotoxic activity (Laphookhieo et al., 2004), effect on central nervous system (Hien et al., 1991), purgative and antirheumatic activity (Yamauchi and Abe, 1987), cardiac stimulant activity (Chen and Zheng, 1987), neurological activities (Iyer and Narendranath, 1975), cardiotoxic activity (Kini and Pai, 1965), etc.

The main objective of this study was to evaluate the antibacterial, cytotoxic and neurophamacological activities of $\mathrm{MeOH}$ extract of $\mathrm{C}$. odollam seeds.

\section{MATERIALS AND METHODS}

\section{Plant material collection and extraction}

The plants were collected from Sundarbans Mangrove forest of Bangladesh in September 2006 and were identified at National Herbarium of Bangladesh (Accession no.: 29788). About $750 \mathrm{~g}$ of pulverized seeds were taken in a clean, flatbottomed glass container and soaked in $950 \mathrm{ml}$ of $80 \%$ methanol. The container with its contents was sealed and kept for a period of 10 days accompanying occasional shaking and stirring. The whole mixture then underwent a coarse filtration by a piece of clean, white cotton material followed by filtration through whatmann filter paper. The filtrate thus obtained was concentrated under ceiling fan followed by vacuum desiccation.

\section{Tests for different Chemical groups}

The crude $\mathrm{MeOH}$ extract was tested for its different chemical groups as alkaloids, flavonoids, gums, reducing sugars, saponins, steroids and tannins (Evans, 1989). In each test 10\% (w/v) solution of the extract in $\mathrm{MeOH}$ was taken unless otherwise mentioned in individual test.

\section{Animals}

Young Swiss-albino mice of either sex, weighing $20-25 \mathrm{~g}$, purchased from the Animal Research Branch of the International Centre for Diarrhoeal Disease and Research, Bangladesh (ICDDR, B) were used for neuropharmacological activity tests. The animals were kept at animal house of Pharmacy Discipline, Khulna University, for adaptation under standard environmental condition and fed with standard diets (ICDDRB formulated).

\section{Microorganisms}

Both gram positive and gram-negative bacterial strains were taken for antibacterial test. The bacterial strains used for the investigation are listed in Table 2.

\section{Drugs}

Pentobarbital sodium (Sigma Chemicals, USA).

\section{Antibacterial activity}

Antibacterial activity of the seed extract was tested against some most common pathogenic gram positive and gram negative bacteria by agar well diffusion method (Rios et al., 1987). In this method measured amount of the test samples are dissolved in definite volumes of solvent to give solutions of known concentration $(50 \mu \mathrm{g} / \mathrm{ml})$. Then three wells were made through the media of the seeded plates, one for the sample, one for the blank and another for the standard (Gentamicin) by using sterile cork borer. Then the samples, blank and standard were applied to the holes by using micropipette with desired amount. The plates were then kept in refrigerator for about $2 \mathrm{~h}$

Table 1. Chemical constituents of C. odollam

\begin{tabular}{ccccccc}
\hline Plant Extract & Alkaloids & Reducing Sugars & Tannins & Gums & Flavonoids & Saponins \\
\hline MeOH extract & + & - & + & - & - & + \\
\hline
\end{tabular}

+: Positive result; -: Negative result 
Table 2. In vitro antibacterial activity of $\mathrm{MeOH}$ extract of C. odolla

\begin{tabular}{lcc}
\hline \multirow{2}{*}{ Bacterial strains } & \multicolumn{2}{c}{ Diameter of zone of inhibition in mm } \\
\cline { 2 - 3 } Gram positive & MeOH extract $(500 \mu \mathrm{g} / \mathrm{hole})$ & Gentamycin $(30 \mu \mathrm{g} / \mathrm{hole})$ \\
Staphylococcus aureus & 06 & 27 \\
Staphylococcus epidermis & 00 & 22 \\
Streptococcus saprophyticus & 16 & 30 \\
Streptococcus pyogenes & 11 & 28 \\
Gram negative & & 28 \\
Salmonella typhi & 15 & 22 \\
Shigella boydii & 00 & 21 \\
Shigella sonnie & 00 & 28 \\
Shigella flexneri & 06 & 26 \\
Shigella dysenteriae & 06 & \\
\hline
\end{tabular}

at $4{ }^{\circ} \mathrm{C}$ to allow the material to diffuse into a considerable area of the medium. Finally the plates were incubated upside down at $37^{\circ} \mathrm{C}$ for 18 - $24 \mathrm{~h}$. After proper incubation, the antibacterial activity was determined by measuring the diameter of zone of inhibition in terms of millimeter with a slide calipers.

\section{Cytotoxic activity}

Cytotoxicity of the extract was tested by using brine shrimp lethality bioassay (Meyer et al., 1982). Test solution (MeOH extract in DMSO) of different concentrations as 2, 4, 8, 16, 32 and 64 $\mu \mathrm{g} / \mathrm{ml}$ was applied to the test tubes containing hatched brine shrimp naupli in sea water followed by counting the survived naupli after $24 \mathrm{~h}$.

\section{Neuropharmacological activity}

\section{i. Pentobarbital induced hypnosis:}

Pentobarbital induced hypnosis test was carried out by the method of Tedeschi and Tedeschi (1968). The test animals were divided into two groups consisting of ten mice in each. Group I was the control group and group II was the test group. Test groups were administered with the $\mathrm{MeOH}$ extract at dose of $25 \mathrm{mg} / \mathrm{kg}$, while the control group animals were supplied with distilled water containing $0.1 \%(\mathrm{v} / \mathrm{v})$ tween-80 at dose of $10 \mathrm{ml} / \mathrm{kg}$. Control vehicle and test sample were administered $60 \mathrm{~min}$ prior to the i.p. injection of pentobarbital at dose of $45 \mathrm{mg} / \mathrm{kg}$. The total sleeping time was recorded for both controls as well as for test group. Total sleeping time represents the time between the loss and regain of righting reflex.

\section{ii. Exploratory behavior:}

This experiment was performed by i) Open field test (Gupta et al., 1971) and ii) Hole cross test (Takagi et al., 1971). The test animals were divided into two groups consisting of five mice in each. Group I was the control group and group II was the test group. Test group was administered with the $\mathrm{MeOH}$ extract at dose of $25 \mathrm{mg} / \mathrm{kg}$ (i.p.), while the control group animals were supplied with $0.1 \%$ (v/v) Tween- 80 (i.p.) at dose of $10 \mathrm{ml} / \mathrm{kg}$. The observations were made on 0 min before injection and 30, 60, 120 and 240 min after injections (i.p.) of the test sample and control vehicle.

\section{Statistical analysis}

Student's $t$-test was used to determine a significant difference between the control group and test group.

\section{RESULTS}

\section{Preliminary phytochemical analysis}

Results of different chemical tests on the methanol 
extract of seeds of $C$. odollam showed the presence of alkaloids, tannins and saponins (Table 1).

\section{Antibacterial activity}

Table 2 showed the antibacterial activity of $C$. odollam relative to that of the standard drug gentamycin. It showed moderate antibacterial activity against Salmonella typhi, Streptococcus pyogenes and Streptococcus saprophyticus where the zone of inhibition was 15,11 and $16 \mathrm{~mm}$ respectively while mild activity against Staphylococcus aureus, Shigella flexneri and Shigella dysenteriae where the zone of inhibition was $06 \mathrm{~mm}$ in each case.

\section{Cytotoxic activity}

In this bioassay, the extract showed lethality against the brine shrimp nauplii. The extract showed different mortality rate at different concentrations. The plot of percent mortality versus $\log$ concentration on the graph paper produced an approximate linear correlation between them. From the graph, the concentrations at which 50 and $90 \%$ mortality occurred were obtained by extrapolation ( $\mathrm{LC}_{50}: 03 \mu \mathrm{g} / \mathrm{ml} ; \mathrm{LC}_{90}$ : $32 \mu \mathrm{g} / \mathrm{ml}$ ) (Table 3).

\section{Neuropharmacological activity}

i. Pentobarbital induced hypnosis:

Table 4 showed the effects of $\mathrm{MeOH}$ extract of $C$. odollam on pentobarbital induced sleeping time. The extract increased total sleeping time. The average duration of sleep was about $56.45 \mathrm{~min}$ at

Table 3. Cytotoxic activity of C. odollam against brine shrimp

\begin{tabular}{ccccccc}
\hline Test sample & $\begin{array}{c}\text { Conc. } \\
(\mu \mathrm{g} / \mathrm{ml})\end{array}$ & $\begin{array}{c}\text { Log } \\
(\text { Conc. })\end{array}$ & $\begin{array}{c}\text { Avg. no. of alive } \\
\text { shrimp }\end{array}$ & $\begin{array}{c}\% \\
\text { mortality }\end{array}$ & $\begin{array}{c}\mathrm{LC}_{50} \\
(\mu \mathrm{g} / \mathrm{ml})\end{array}$ & $\begin{array}{c}\mathrm{LC}_{90} \\
(\mu \mathrm{g} / \mathrm{ml})\end{array}$ \\
\hline \multirow{5}{*}{ MeOH extract } & 2 & 0.30 & 07 & 30 & & \\
& 4 & 0.60 & 04 & 60 & & 32 \\
Me. extract of C. odollam & 8 & 0.90 & 03 & 70 & 03 & 30 \\
\hline
\end{tabular}

Table 4. Effect of C. odollam on pentobarbital induced hypnosis

\begin{tabular}{cccc}
\hline Animal group & Treatment(i.p.) & Time of onset of sleep (min) & Total sleeping time (min) \\
\hline I. Control & $0.1 \%$ Tween 80 solution10 ml $/ \mathrm{kg}$ & $3.36 \pm 0.457$ & $49.09 \pm 2.44$ \\
II.Test group & MeOH Extract $25 \mathrm{mg} / \mathrm{kg}$ & $4.27 \pm 0.304^{*}$ & $56.45 \pm 5.61^{*}$ \\
\hline
\end{tabular}

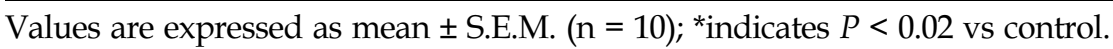

Table 5. Effect of C. odollam on exploratory behavior in mice

\begin{tabular}{|c|c|c|c|c|c|}
\hline \multirow{2}{*}{ Group } & \multicolumn{5}{|c|}{ Response at } \\
\hline & $0 \mathrm{~min}$ & $30 \mathrm{~min}$ & $60 \mathrm{~min}$ & $120 \mathrm{~min}$ & $240 \mathrm{~min}$ \\
\hline \multicolumn{6}{|c|}{ Open Field Test } \\
\hline I. Control & $113 \pm 16.27$ & $94 \pm 23.19$ & $83 \pm 22.3$ & $83 \pm 18.51$ & $86 \pm 22.85$ \\
\hline $\begin{array}{l}\text { II. MeOH extract } \\
25 \mathrm{mg} / \mathrm{kg}\end{array}$ & $107 \pm 20.78$ & $82 \pm 10.63$ & $63 \pm 9.45$ & $27 \pm 4.63^{*}$ & $17 \pm 3.60^{*}$ \\
\hline \multicolumn{6}{|c|}{ Hole Cross Test } \\
\hline I. Control & $1 \pm 0.26$ & $3 \pm 0.58$ & $4 \pm 1.0$ & $4 \pm 1.29$ & $5 \pm 0.97$ \\
\hline $\begin{array}{l}\text { II. MeOH extract } \\
25 \mathrm{mg} / \mathrm{kg}\end{array}$ & $0.33 \pm 0.21$ & $1.16 \pm 0.74$ & $2.5 \pm 1.147$ & $1.5 \pm 0.50$ * & $0.33 \pm 0.21^{* *}$ \\
\hline
\end{tabular}

Values are expressed as mean \pm S.E.M. $(\mathrm{n}=5)$ * indicates $P<0.02 ; * *$ indicates $P<0.01$ vs control. 
dose of $25 \mathrm{mg} / \mathrm{kg}$ where as in control group it was about $49.09 \mathrm{~min}$. Thus the results showed that the $\mathrm{MeOH}$ extract of $\mathrm{C}$. odollam potentiated the pentobarbital induced sleeping time in mice.

\section{ii. Exploratory behavior:}

It was observed that the extract caused a significant $(P<0.02)$ decrease in the open field score (Table 5) and decrease in the number of hole crossed from one chamber to another chamber significantly $(P<0.001)$ (Table 5$)$ in mice at the dose of $25 \mathrm{mg} / \mathrm{kg}$.

\section{DISCUSSION}

C. odollam is a poisonous tree, which is responsible for about $50 \%$ of the plant poisoning cases and $10 \%$ of the total poisoning cases in Kerala, India. It is used both for suicide and homicide. Interestingly, the same species available in Coastal region of Bangladesh is not too much poisonous, and even the local people use the fleshy portion of the fruit as food. Previously we reported that its barks were not toxic to albino mice $\left(\mathrm{LD}_{50}: 750 \mathrm{mg} / \mathrm{kg}\right)$. In the present study, $\mathrm{MeOH}$ extract of seed kernels were screened for its biological activities. The $\mathrm{LD}_{50}$ value was found to be $500 \mathrm{mg} / \mathrm{kg}$. Odollam Seeds were more toxic compared to its barks, and was carefully used. Due to its toxicity lower doses were used in antibacterial, cytotoxic and neuropharmacological activity tests.

In vitro antibacterial activity of the extract was determined by agar-well diffusion method (Rios et al., 1987). Agar-well diffusion method is widely acceptable for the preliminary screening of antimicrobial activity. It is essentially a qualitative or semi quantitative test indicating the sensitivity or resistance of microorganisms to the test materials (Roland, 1982). On the basis of the result of agarwell diffusion method, it can be concluded that the extract possesses mild to moderate antibacterial activity.

The cytotoxic activity of extract was tested by using brine shrimp lethality bioassay. It is a recent development in the bioassay for the bioactive compounds. Brine shrimp lethality bioassay indicates cytotoxicity as well as a wide range of pharmacological activities such as antimicrobial, pesticidal, antitumor, etc. (Anderson et al, 1988). The extract was found to show potent activity against the brine shrimp nauplii. Therefore the positive response obtained in this assay suggests that the extract may contain antitumor, antibacterial or pesticidal compounds.

Neuropharmacological activity was tested by pentobarbital induced sleeping time test and the tests for exploratory behavior. Pentobarbital shorten the onset of sleep and increases sleep duration. The $\mathrm{MeOH}$ extract of $\mathrm{C}$. odollam potentiated the pentobarbital induced sleeping time in mice, which suggests its central depressant activity (Perez et al. 1998), thus suggesting the probable tranquilizing action (Capasso et al. 1996). The extract also made mice to reduce their behavioral exploration, which further supports the central sedative properties of the extract. The overall results tend to predict the central nervous system depressant action of the extract.

In conclusion, it can be suggested that the $\mathrm{MeOH}$ extract of $\mathrm{C}$. odollam seeds possesses antibacterial, cytotoxic and CNS depressant effects, which correlate well with the traditional use of the plant. The activity of the seed extract may be due to the presence of alkaloid and/or saponins present in it. Further researches, however, are essential to find out the active principles responsible for these activities.

\section{REFERENCES}

Ahmed F, Hossain MH, Rahman AA, Shahid IZ. (2006) Antinociceptive and CNS depressant activity of the bark of Cerbera odollam Gaertn. Orient. Pharm. Exp. Med. 6, 344-348.

Anderson JE, Chang CJ, McLaughlin JL. (1988) Bioactive components of Allamanda schottii. J. Nat. Prod. 51, 307-308. 
Capasso A, Aquino R, De Simone F, Sorrentino L. (1996) Neuropharmacological effects of extracts from Sickingia williamsii. J. Pharm. Pharmacol. 48, 592595.

Chen JS, Zheng S. (1987) Poisonous plants of China, p75, Science press, Beijing.

Chopra RN, Nayar SL, Chopra IC. (1956). Glossary of Indian Medicinal Plants, CSIR, New Delhi.

Evans WC. (1989) Trease and Evan's Textbook of Pharmacognosy. 13 th edition. Cambridge University Press, London.

Gupta BD, Dandiya PC, Gupta M. (1971) A psychopharmacological analysis of behavior in rat. Jpn. J. Pharmacol. 21, 293-298.

Hien TT, Navarro-Delmasure C, Vy T. (1991) Toxicity and effects on the central nervous system of a Cerbera odollam leaf extract. J. Ethnopharmacol. 34, 201-206.

Iyer GV, Narendranath M. (1975) A preliminary report on the neurological manifestation of Cerbera odollam poisoning. Indian J. Med. Res. 63, 312-314.

Kini PM, Pai KN. (1965) Cardiotoxic effects of Cerbera odollam. Indian Heart J. 17, 263-270.

Kirtikar KR, Basu BD. (1987) Indian Medicinal Plants, vol. III, $2^{\text {nd }}$ ed., pp. 1552-1553. International Book Distributors, India.

Laphookhieo S, Karakai CX, Chantrapromma K. (2004) Cytotoxic cardenolide glycoside from the seeds of Cerbera odollam. Phytochemistry 65, 507-510. Meyer BN, Ferrigni NR, Putnam JB, Jacobsen LB, Nichols DE, McLaughlin JL. (1982) Brine shrimp: a convenient general bioassay for active plant constituents. Planta Med. 45, 31-34.

Perez GRM, Perez LJA, Garcia DLM, Sossa MH (1998) Neuro-pharmacological activity of Solanum nigrum fruit. J. Ethnopharmacol. 62, 43-48.

Rios JL, Recio MC, Villar A. (1987) Antimicrobial activity of selected plants employed in the Spanish Mediterranean area. J. Ethnopharmacol. 21, 139-152.

Roland R. (1982) Antibiotics-An introduction. Hoffman La-Roche \&Co, Switzerland, p. 70-71.

Rollet B. (1981) Bibliography on mangroves research. 1600-1975. p. 479, UNESCO Paris, Information Retrieval Ltd., London.

Takagi K, Watanabe M, Saito H. (1971) Studies on the spontaneous movement of animals by the hole cross test: Effect of 2-dimethylaminoethan; its acylesters on the central nervous system. Jpn. J. Pharmacol. 21, 797-810.

Tedeschi LG, Tedeschi CG. (1968) Adipogenesis in the neonatally thymectomised rat. J. Pathol. Bacteriol. 96, 473-480.

Yamauchi T, Abe F. (1987) Studies on Cerbera IV, polar cardenolide glycoside from the leaves of Cerbera odollam and Cerbera manghas. Chem. Pharm. Bull. 35, 4813-4818. 